\title{
HISTORICAL HYDROPOWER PROJECTS AND DEMOGRAPHIC PROCESSES - CASE STUDY MUNICIPALITY OF MALI ZVORNIK
}

\author{
Rajko Golić ${ }^{*}{ }^{1}$, Marko Joksimović, Dejan Šabić \\ "University of Belgrade - Faculty of Geography, Belgrade
}

\begin{abstract}
Construction of dams and creation of artificial water reservoirs affect the transformation of landscape and socioeconomic structure of geospace. Some of the most significant changes are related to demographic processes, manifested by the resettlement of people from submerged parts of the settlement and changes in the demographic structure. The article analyzes the impact of the building of the hydropower plant "Zvornik" and artificial Zvornik Lake on demographic processes in Municipality of Mali Zvornik in the period 1948-1961. Analysis of statistical data shows that the changes of population, population density, number of households, average household size, sex ratio, ethnicity and economic structure deviate from the usual demographic trends. Changes were detect in settlements that, after the construction of the dam, were located on the shore of the newly formed Zvornik Lake. These changes were directly related to geographical and socio-economic transformation during the construction of HPP "Zvornik".
\end{abstract}

Key words: Municipality of Mali Zvornik, HPP "Zvornik", Zvornik Lake, demographic changes, water reservoirs.

\section{Introduction}

Creation of artificial water reservoirs is one of the most complex and functionally the most powerful mechanisms of transformation of the geo-

${ }^{1}$ Corresponding author: R. Golić, University of Belgrade - Faculty of Geography, Studentski trg 3/III, 11,000 Belgrade, Serbia; e-mail: rgolic@gef.bg.ac.rs 
space. Besides the complex changes in the physical-geographical, ecological and biogeographical structure of space, its socio-economic component has also been transformed (Милинчић, Павловић \& Шабић, 2010). There are different opinions about the impact of reservoirs on the geographical space: creating new cultural landscapes; ennobling of space; changing the cultural and social patterns of existence; transforming the components of functionality of geospace, land use and economic activities; radically changing the geographical environment, which leads to the complete erasure of all human heritage, etc. (Гавриловић, Михајловић, Макаров \& Милинчић, 2011).

Water reservoirs to a greater or lesser extent affects socioeconomic processes. There are submerge of settlements, agricultural land, roads and other infrastructure systems; changes in population and some demographic indicators; changes in the structure of economic activity, destruction of natural resources, etc. The most problematic effect is the resettlement of the population due to the submerge of settlements; it is largely considered the most severe form of social impact generated by dams (Kirchherr \& Charles, 2016). Resettlement has probably received more attention than any other category of social impact of dams; it was the subject of research by a large number of authors (Голић, Јоксимовић \& Крстић, 2014; Hadi, 2017; Kirchherr \& Charles, 2016; Milinčić et al., 2010; Namy, 2007; Tan \& Hugo, 2011; Tilt, Braun \& He, 2009; WCD, 2000; Wilmsen, 2017; Wilmsen \& Van Hulten, 2017; Yan, Shi, Hu \& Wang, 2017; Yen, 2003, etc.). Dam construction implies abrupt termination of the settlement continuity, which in some cases is compensated by raising new settlements in other locations (Golić et al., 2014). Migration and resettlement, as primary impact, results in a wide array of subsequent social impacts, including changes in household size and structure, changes in employment and income-generating opportunities, alteration of access and use of land and water resources, changes in social networks and community integrity (Tilt et al., 2009). Such changes essentially alter the socioeconomic structure of geospace. New standards of its valorisation, communal equipping and spatial planning are being created (Голић et al., 2014).

The demographic impact of the construction of artificial reservoirs relate primarily to the decrease in the population, number of households and population density, due to emigration from the affected areas. These resettlement are carried out in a planned manner and are mostly involuntary, which in some cases can lead to different forms of resistance and sociopolitical conflicts (Gutman, 1994; Wilmsen \& Webber, 2017; Yen, 2003). The socioeconomic status of displaced persons is generally worsening, as resettlement programmes have focused on physical relocation rather than the economic and social development of the displaced (WCD, 2000). Different 
impoverishment risks through displacement are: landlessness, joblessness, homelessness, marginalization, food insecurity, morbidity, and social disarticulation (Kirchherr \& Charles, 2016).

Construction of reservoirs can lead to the displacement of millions of people around the world and the "sacrifice" of entire residential areas. Some 40-80 million people have been physically displaced by dams worldwide in the second half of the 20th century (Hadi, 2017; Namy, 2007; Nguyen, Pham \& de Bruyn, 2017; Owusu, Obour \& Nkansah, 2017; WCD, 2000). Only in China, 12 million people have been displaced by 85,000 reservoirs since 1949 (an average of 240,000 per year) (Wu, Penning, Zeng, Li \& Chappell, 2016). The most dramatic example is the Three Gorges Dam on the Yangtze River; the ultimate number of displaced people was estimated to be some 1.3 million (Tan \& Hugo, 2011; Wilmsen, 2017; Yang, Smith \& Sivakumar, 2017).

The construction of the dam affects the changes of some demographic structures (sex, age, nationality, economic structure, etc.). Such demographic trends largely deviate from the usual population trends and are mostly depend on overall socioeconomic processes at the time of dam construction and the formation of reservoirs.

In Serbia, the construction of the dams did not lead to the large-scale displacement of people. The largest demographic changes, followed by forced emigration of several hundred or thousands of people, are related to the construction of hydropower plants (HPP) "Đerdap 1" (Danube), "Zvornik" and "Bajina Bašta" (Drina), "Zavoj" (Visočica), HPPs on Vlasina, etc., when submerged parts of villages or smaller urban settlements (Голић et al., 2014).

The construction of the HPP "Zvornik" on the Drina and the creation of the Zvornik Lake (1948-1955) directly influenced the demographic changes in the seven settlements of the Municipality of Mali Zvornik. Since these settlements has small population size, the displacement even of a small number of inhabitants has affected significant changes in some demographic indicators in the 1948-1953 and 1953-1961 intercensal periods. Changes in the number of inhabitants and households, average household size, sex ratio, ethnic composition and structure of the active population by activity in the period 1948-1961, especially in the municipal center, can not be compared to any projected population trends, as they differ largely from any linearity and demographic regularity. Therefore demographic changes in the Municipality of Mali Zvornik in the period 1948-1961 can only be explained by taking into account the specific socioeconomic context during the construction of the first hydropower plant on Drina. 


\section{Transformation of the regional structure of geospace at the time of the construction of the HPP "Zvornik"}

Significant spatial and socio-economic changes in the territory of the Municipality of Mali Zvornik occurred in the mid-20th century, when HPP "Zvornik" was built - the first hydropower plant on the Drina. Hydroelectric power plant was built in the period 1948-1955 (Golić \& Joksimović, 2013). HPP "Zvornik" is the most important economic facility in the Municipality of Mali Zvornik, which at the beginning of the 21st century is the holder of the economic development of the municipality (Pavlović, Golić \& Šabić, 2010).

The construction of hydropower plant and formation of Zvornik Lake (covers a surface area of $13.5 \mathrm{~km}^{2}$ ) created new geographic physiognomy, by which this part of Podrinje became recognizable. About 800 ha of land have been submerged, of which 680 ha of arable land (according to other data, 1,300 ha have been submerged). The Zvornik Lake affects the change of microclimate, river regime of the Drina, groundwater regime, water quality, biodiversity, fish migration, deposition of sediments in the reservoir, etc. (Голић, 2010a). By deposition of sediments in the period 1955-2015, the original reservoir volume was reduced by $60.1 \%$ (Голић, 2015; Matić et al., 2015).

The construction of the HPP "Zvornik" also transformed the network of settlements in the territories of the municipalities of Mali Zvornik and Zvornik. By raising the level of water, the lower parts of the settlement on both sides of the Drina were submerged, which resulted the emigration of the population from the coastal belt. Expropriation of several thousand lots was carried out and compensation was paid to households whose homes and property remained under water. About 600 houses were flooded (Ristanović, 1985), and according to other source, 900 households and $85 \mathrm{~km}$ of local roads were submerged (Станковић, 2004). From the total of 12 settlements in the Municipality of Mali Zvornik, parts of seven settlements were submerged, which caused the displacement of the population.

Mali Zvornik suffered the biggest morphological and functional changes. The development of this settlement is closely connected with the construction of HPP "Zvornik", because the old settlement was demolished and new one was formed (Pavlović et al., 2010). Residents were displaced to a new settlement downstream of the dam or to Zvornik, while some got land and houses in other places and moved away. At the same time as the disappearance of old Mali Zvornik - a village of farmers and raftsmen, a new Mali Zvornik was created - modern urban settlement (Голић, 2010a). 
Upstream from Mali Zvornik, parts of six villages were submerged (Sakar, Budišić, Amajić, Čitluk, Culine and Velika Reka). The most fertile lands on the shore of Drina is submerged, and the villages were moved to a higher ground along the coast of Zvornik Lake, a few meters above the new coastline. Leaving without agricultural land as the main source of income, villagers were forced to evict. The greatest physiognomic changes were suffered by the village Culine; and at least Velika Reka, located in the most upstream part of the lake, whose arable areas largely remained above the water level (Голић, 2010a). The remaining five villages in the municipality of Mali Zvornik are located downstream from the HPP "Zvornik" (Radalj, Brasina and Donja Borina) or in the hilly and mountainous interior (Donja Trešnjica and Voljevci), so there was no submerge in their areas.

\section{Methods and data}

In order to study the direct impact of the construction of the HPP "Zvornik" on demographic changes in Municipality of Mali Zvornik, the census data were analyzed in 1948, 1953 and 1961. The census of population in 1948 precedes the construction of the HPP "Zvornik", the census in 1953 was done at the time of construction, and the 1961 census points to demographic indicators after the formation of the Zvornik Lake. By means of a comparative analysis of these three censuses, demographic processes in Municipality of Mali Zvornik can be followed before, during and after the construction of a hydroelectric power plant.

The paper analyzes demographic trends in Mali Zvornik, in six villages on the shore of the artificial lake, and in other rural settlements in the municipality of Mali Zvornik. The results obtained made it possible to determine in which settlements there was a deviation from the expected demographic trends, and in which they did not, as well as explain the causes of these changes.

Demographic indicators were processed by statistical methods and presented in tabular form. In addition to statistical sources, the article also used literature on the subject of study, which allowed the reconstruction of spatial changes at the time of the construction of the HPP "Zvornik", which also influenced the demographic processes. 


\section{Results and discussion}

\section{Changes in population and population density}

Changes in the number of inhabitants and households in Mali Zvornik and neighboring rural settlements in the period 1948-1961 show numerous specifics that deviate from the usual demographic trends of that time in Serbia. These changes were to a lesser extent under the influence of natural growth, and more under the influence of migrations caused by the construction of the dam and the reservoir (the emigration from the submerged parts of Mali Zvornik and six rural settlements, the immigration of construction workers to Mali Zvornik and their emigration after the completion of dam construction (table 1).

During the intercensal period 1948-1953 (construction of the power plant) population growth in Municipality of Mali Zvornik was high. The number of inhabitants rose by almost a one-third in just five years - from 9,036 to 12,004 (growth rate 32.8\%). In this five-year period, the Municipality of Mali Zvornik had the highest population growth rate in Serbia. Mali Zvornik and the villages on the coast of Zvornik Lake had even more intense demographic growth - the population has grown from 3,432 to 5,720 , or by two-thirds (growth rate $66.7 \%$ ). The causes of rapid population growth in Mali Zvornik and rural settlements were different. In rural settlements, population growth was largely influenced by a high natural increase. The population of Mali Zvornik was increased mainly by the immigration of workers who were working on the construction of the HPP "Zvornik".

Population growth in this intercensal period was the most intense in Mali Zvornik. The beginning of the construction of HPP "Zvornik" in 1948 caused the immigration of people who were engaged in the construction of the then largest hydroelectric power plant in Serbia. In the first construction phase in 1948, more than 1,500 workers moved to the Mali Zvornik (Milinković, 2005). Most of the new residents of Mali Zvornik were unskilled labor force, mostly peasants and unemployed people from towns and cities. In the period 1948-1953 the population of Mali Zvornik increased from 768 to 2,783 (growth rate $262.4 \%$ for only five years). Mali Zvornik was a urban settlement with the highest population growth rate in Serbia.

In some periods of the building of the dam, in Mali Zvornik there were up to 4,000 construction workers, mainly from Azbukovica, Jadar and Rađevina (Serbia), while the professional workforce was settled from Vojvodina, Macedonia, Slovenia and Dalmatia (Ђурић, 1960). Since the immigrant 
workers were more numerous than the autochthonous population, the new socio-cultural identity of Mali Zvornik was formed. During the same intercensal period 1948-1953 the opposite process took place - the involuntary resettlement of parts of the local residents, but the emigration was incomparably less than the immigration of construction workers and natural growth, so that the population multiplied (Голић et al., 2014).

Table 1 - Population in the period 1948-1961

\begin{tabular}{|l|c|c|c|c|c|}
\hline \multirow{2}{*}{ Settlement } & \multicolumn{3}{|c|}{ population } & \multicolumn{2}{c|}{ growth rate (\%) } \\
\cline { 2 - 6 } & $\mathbf{1 9 4 8}$ & $\mathbf{1 9 5 3}$ & $\mathbf{1 9 6 1}$ & $\mathbf{1 9 4 8 - 1 9 5 3}$ & $\mathbf{1 9 5 3 - 1 9 6 1}$ \\
\hline Mali Zvornik & $\mathbf{7 6 8}$ & $\mathbf{2 , 7 8 3}$ & $\mathbf{1 , 8 8 8}$ & $\mathbf{2 6 2 . 4}$ & $\mathbf{- 3 2 . 2}$ \\
\hline Amajić & 187 & 189 & 161 & 1.1 & -14.8 \\
\hline Budišić & 306 & 481 & 346 & 57.2 & -28.1 \\
\hline Velika Reka & 661 & 721 & 680 & 9.1 & -5.7 \\
\hline Sakar & 451 & 423 & 499 & -6.2 & 18.0 \\
\hline Culine & 688 & 711 & 544 & 3.3 & -23.5 \\
\hline Čitluk & 371 & 412 & 370 & 11.1 & -10.2 \\
\hline $\begin{array}{l}\text { villages on the shore of } \\
\text { Zvornik Lake (total) }\end{array}$ & $\mathbf{2 , 6 6 4}$ & $\mathbf{2 , 9 3 7}$ & $\mathbf{2 , 6 0 0}$ & $\mathbf{1 0 . 2}$ & $\mathbf{- 1 1 . 5}$ \\
\hline $\begin{array}{l}\text { Mali Zvornik + villages on } \\
\text { the shore of Zvornik Lake }\end{array}$ & $\mathbf{3 , 4 3 2}$ & $\mathbf{5 , 7 2 0}$ & $\mathbf{4 , 4 8 8}$ & $\mathbf{6 6 . 7}$ & $\mathbf{- 2 1 . 5}$ \\
\hline other rural settlements & $\mathbf{5 , 6 0 4}$ & $\mathbf{6 , 2 8 4}$ & $\mathbf{7 , 0 9 5}$ & $\mathbf{1 2 . 1}$ & $\mathbf{1 2 . 9}$ \\
\hline $\begin{array}{l}\text { Municipality of Mali } \\
\text { Zvornik (total) }\end{array}$ & $\mathbf{9 , 0 3 6}$ & $\mathbf{1 2 , 0 0 4}$ & $\mathbf{1 1 , 5 8 3}$ & $\mathbf{3 2 . 8}$ & $\mathbf{- 3 . 5}$ \\
\hline
\end{tabular}

Source: P3C, 2014a.

In the villages of the Municipality of Mali Zvornik in the period 19481953, population growth was slower than in the municipal center. Since construction workers settled almost exclusively in Mali Zvornik, the growth of the rural population was mostly affected by the high natural increase. In the six villages of the Municipality of Mali Zvornik, which are located downstream from the dam, in the period 1948-1953 the population increased from 2,664 to 2,937 (10.2\%). Budišić had the most intense population growth (57.3\%). Population decline was expressed only in Sakar (-6.2\%), due to the relocation of a part of the male population in Mali Zvornik and employment on the construction site. Statistical data indicate that the construction of the HPP "Zvornik" in the period 1948-1953 did not significantly affect the demo- 
graphic changes in these six villages, because only at the end of this period began filling the reservoir with water and submerging of parts of the villages. At the same time, in five villages that are not located on Zvornik Lake, population has increased from 5,604 to 6,284 people (growth rate 12,1\%).

In the next intercensal period (1953-1961), population growth in most settlements of the Municipality of Mali Zvornik showed completely opposite trends. Although the natural increase was still high, in some rural settlements there was a marked depopulation. The completion of the construction of HPP "Zvornik" in 1955, the filling of the reservoir and the sinking of parts of the settlements caused intense emigration. A part of the inhabitants of Mali Zvornik and six rural settlements (Sakar, Budišić, Amajić, Čitluk, Culine and Velika Reka) was left without houses and agricultural land, due to which involuntary resettlement was carried out. Positive natural increase could not compensate for the negative migration balance, so in 1961, in the Municipality of Mali Zvornik, 11,583 inhabitants were enumerated - 3.5\% less than in 1953.

In this intercensal period, demographic trends in the Municipality of Mali Zvornik were extremely uneven. The population of Mali Zvornik and six villages on the shore of a newly formed artificial lake decreased by $21.5 \%$ between 1953 and 1961. Such processes were very different from the demographic trends in Western Serbia at that time (which are characterized by a steady growth of the population due to high natural growth), and indicate the great impact of the construction of the dam on the population change. By contrast, the five villages that are not on the shore of Zvornik Lake have had a demographic growth. Since there was no submerging of land in these villages, there was no forced displacement of peoples. Due to the high birth rate and immigration from the villages that were endangered by the rise of water level in reservoir, the population increased from 6,284 to 7,095 (growth rate 12,9\%).

In 1961, Mali Zvornik had 1,888 residents - a one-third less than in 1953 (growth rate $-32.2 \%$ ). Contrary to the previous intercensal period, between 1953 and 1961 this settlement had the lowest population growth rate among the municipal centers in Serbia. The sharp population decline is a consequence of the forced emigration of the local population, but also the emigration of the part of construction workers. When the construction of HPP "Zvornik" was completed in 1955, some of the construction workers moved to the construction site of HPP "Bajina Bašta", while the other part of the workers permanently settled in Mali Zvornik. The choice of Mali Zvornik as a place of permanent residence has been influenced by cheap land for individual housing construction, privileges received by former workers at the 
construction of HPP "Zvornik", possibility of employment in Loznica and Zvornik, family relationship, etc. (Голић, 2010a).

In six villages, which by the formation of the reservoir lost part of their area, in 1961 there were 2,600 inhabitants - 11.5\% less than in 1953. The population of Budišić decreased by $28.1 \%$, Culine by $23.5 \%$, Amajić by $14.8 \%$ and Čitluk by $10.2 \%$. The smallest population decline was recorded in Velika Reka $(-5,7 \%)$, because in this village most of the agricultural land remained above the water level. Only in Sakar there was an population increase by $18 \%$, due to the return of local workers who were engaged in the construction site.

Some villagers whose houses and property have been submerged have been moved to other settlements of Municipality of Mali Zvornik, and most of them was resettled to other parts of Serbia and the former Yugoslavia. Most locals were resettled in the period 1953-1955. The muslim population of Mali Zvornik and Sakar was relocated to Zvornik, Divič, Drinjača and Janja (Bosnia and Herzegovina). The Serbs were moved to Loznica, Lešnica, Šabac, Mačva (villages Ribari, Prnjavor, etc.), Srem (Tovarnik, Nikinci and Ogar), Banat (Omoljica near Pančevo), Slavonia (Markušica near Vinkovci) etc. One village in the Municipality of Markušica (Croatia) is called Podrinje, which indicates the origin of its population (Голић, 2010a). Resettlement of the population was accompanied by conflicts because the locals did not want to accept the expropriation of land and the forced change of the place of residence (Голић, 2010b).

Table 2 - Population density (people per $\mathrm{km}^{2}$ ) in the period 1948-1961

\begin{tabular}{|l|c|c|c|}
\hline Settlement & $\mathbf{1 9 4 8}$ & $\mathbf{1 9 5 3}$ & $\mathbf{1 9 6 1}$ \\
\hline Mali Zvornik & 84.5 & 306.2 & 207.7 \\
\hline Amajić & 152.0 & 153.7 & 130.9 \\
\hline Budišić & 35.5 & 55.8 & 40.1 \\
\hline Velika Reka & 49.8 & 54.3 & 51.2 \\
\hline Sakar & 62.6 & 58.7 & 69.2 \\
\hline Culine & 72.6 & 75.0 & 57.4 \\
\hline Čitluk & 48.4 & 53.8 & 48.3 \\
\hline villages on the shore of Zvornik Lake (total) & $\mathbf{5 6 . 1}$ & $\mathbf{6 1 . 9}$ & $\mathbf{5 4 . 8}$ \\
\hline other rural settlements & $\mathbf{4 4 . 0}$ & $\mathbf{4 9 . 3}$ & $\mathbf{5 5 . 7}$ \\
\hline Municipality of Mali Zvornik (total) & $\mathbf{4 9 . 1}$ & $\mathbf{6 5 . 3}$ & $\mathbf{6 3 . 0}$ \\
\hline
\end{tabular}

Source: authors, according to P3C, 2014b. 
Variations in the population size also followed changes in population density (table 2). In Mali Zvornik, the population density in 1948 was 84.5 inhabitants per $\mathrm{km}^{2}$. The influx of construction workers affected the sudden increase in the population density in 1953 (306.2 per $\left.\mathrm{km}^{2}\right)$, and their emigration to a sharp decline in 1961 (207.2 per $\left.\mathrm{km}^{2}\right)$. In the villages on the shore of Zvornik Lake, the population density in the period 1948-1953 increased from 56.1 to 61.9 person per $\mathrm{km}^{2}$, and then to 1961 it was reduced to 54.8 per $\mathrm{km}^{2}$. In the other rural settlements in the Municipality of Mali Zvornik, where demographic processes were not affected by the construction of the dam, the population density in the period 1948-1961 had a continuous growth, from 44 to 49.3 and 55.7 people per $\mathrm{km}^{2}$.

\section{Changes in the number and size of households}

In the period 1948-1953, the number of households in Municipallity of Mali Zvornik was doubled - from 1,371 to 2,772 (table 3); the achieved growth rate (102.2\%) was the highest in Serbia. Between 1953 and 1961, the number of households decreased by almost a one-fifth (2,257 households in 1961), and the growth rate $(-18.6 \%)$ was the lowest in Serbia. These sharp variations are the result of a change in the number of households in the municipal center, which was extreme unusual and very much deviated from the general demographic trends.

Table 3 - Households in the period 1948-1961

\begin{tabular}{|l|c|c|c|c|c|}
\hline \multirow{2}{*}{ Settlement } & \multicolumn{3}{|c|}{ households } & \multicolumn{2}{c|}{ growth rate (\%) } \\
\cline { 2 - 6 } Mali Zvornik & $\mathbf{1 9 4 8}$ & $\mathbf{1 9 5 3}$ & $\mathbf{1 9 6 1}$ & $\mathbf{1 9 4 8 - 1 9 5 3}$ & $\mathbf{1 9 5 3 - 1 9 6 1}$ \\
\hline Amajić & $\mathbf{1 4 2}$ & $\mathbf{1 , 4 1 5}$ & $\mathbf{4 9 1}$ & $\mathbf{8 9 6 . 5}$ & $\mathbf{- 6 5 . 3}$ \\
\hline Budišić & 29 & 27 & 35 & -6.9 & 29.6 \\
\hline Velika Reka & 54 & 79 & 60 & 46.3 & -24.1 \\
\hline Sakar & 88 & 89 & 96 & 1.1 & 7.9 \\
\hline Culine & 70 & 74 & 98 & 5.7 & 32.4 \\
\hline Čitluk & 102 & 102 & 106 & 0.0 & 3.9 \\
\hline $\begin{array}{l}\text { villages on the shore of } \\
\text { Zvornik Lake (total) }\end{array}$ & 55 & 54 & 60 & -1.8 & 11.1 \\
\hline other rural settlements & $\mathbf{3 9 8}$ & $\mathbf{4 2 5}$ & $\mathbf{4 5 5}$ & $\mathbf{6 . 8}$ & $\mathbf{7 . 1}$ \\
\hline $\begin{array}{l}\text { Municipality of Mali Zvornik } \\
\text { (total) }\end{array}$ & $\mathbf{1 , 3 7 1}$ & $\mathbf{2 , 7 7 2}$ & $\mathbf{2 , 2 5 7}$ & $\mathbf{1 0 2 . 2}$ & $\mathbf{- 1 8 . 6}$ \\
\hline
\end{tabular}

Source: P3C, 2014b. 
In the first analyzed period (1948-1953), the number of households in Mali Zvornik increased almost 10 times - from 142 to 1,415 (table 3), and the average households size was reduced from 5.4 to 2 members (table 4). In this period, households growth rate in Mali Zvornik (896.5\%) was among the largest in Serbia (table 3). This is a consequence of the large influx of construction workers in Mali Zvornik, and each worker is enumerated as a separate single-member households.

After the completion of the construction of the HPP "Zvornik" in 1955, most of the construction workers (single-member households) moved out of Mali Zvornik, which caused a rapid population decline. The 1961 census in Mali Zvornik enumerated 491 households - almost three times less than in 1953. In the period 1953-1961 households growth rate in Mali Zvornik amounted to $-65.3 \%$ and was the smallest among urban settlements in Serbia (table 3). Emigration of the construction workers also affected the growth of the average household size to 3.8 members in 1961 (table 4).

Table 4 - Average households size in the period 1948-1961

\begin{tabular}{|l|c|c|c|}
\hline Settlement & $\mathbf{1 9 4 8}$ & $\mathbf{1 9 5 3}$ & $\mathbf{1 9 6 1}$ \\
\hline Mali Zvornik & $\mathbf{5 . 4}$ & $\mathbf{2 . 0}$ & $\mathbf{3 . 8}$ \\
\hline Amajić & 6.4 & 7.0 & 4.6 \\
\hline Budišić & 5.7 & 6.1 & 5.8 \\
\hline Velika Reka & 7.5 & 8.1 & 7.1 \\
\hline Sakar & 6.4 & 5.7 & 5.1 \\
\hline Culine & 6.7 & 7.0 & 5.1 \\
\hline Čitluk & 6.7 & 7.6 & 6.2 \\
\hline villages on the shore of Zvornik Lake (total) & $\mathbf{6 . 7}$ & $\mathbf{6 . 9}$ & $\mathbf{5 . 7}$ \\
\hline other rural settlements & $\mathbf{6 . 7}$ & $\mathbf{6 . 7}$ & $\mathbf{5 . 5}$ \\
\hline Municipality of Mali Zvornik (total) & $\mathbf{6 . 6}$ & $\mathbf{4 . 3}$ & $\mathbf{5 . 1}$ \\
\hline
\end{tabular}

Source: P3C, 2014b.

In rural settlements, the impact of the construction of HPP "Zvornik" on the change in the number of households was less pronounced. In the villages on the shore of Zvornik Lake the number of households in the period 1948-1953 increased by 6.8\% (table 3). A significant increase was achieved only in Budišić (46.3\%), while in other settlements there was a slight increase, decrease or stagnation. In this intercensal period, the average households size was high (6.7 members in 1948 and 6.9 members in 1953), which 
is a consequence of high natural growth, the existence of large joint families (the so-called "zadruge"), but also the fact that no immigrant workers. An increase in the average households size was recorded in all villages (table 4). The only exception is Sakar, where there has been a decrease from 6.4 to 5.7 members, because in this settlement a certain number of single-member households (construction workers) were enumerated.

In the period 1953-1961 in the villages on the shore of Zvornik Lake, the number of households increased to 455 (growth rate 7.1\%). According to table 3 , it is noted that the number of households has grown, although the number of inhabitants has declined due to displacement of the population. This indicates to the intensification of socioeconomic processes (deagrarization, extinction of the traditionl rural joint families, division of agricultural land, reduction in birth rates, etc.), which also affected the decrease in the average households size (5.7 members in 1961). The number of households was reduced only in Budišić (by 24.1\%), which has lost the largest percentage of population by involuntary resettlement among all rural settlement in the Municipality of Mali Zvornik.

In the rural settlements of the Municipality of Mali Zvornik that were not threatened by the construction of the reservoir, the number of households continued to grow from 831 (1948) to 1,311 (1961), and households growth rates were $12.2 \%$ and $40.7 \%$, respectively (table 3 ). A faster increase in the number of households in these settlements compared to villages on the shore of Zvornik Lake can be explained by the fact that in their areas there was no submerging of land and planned displacement of the population.

\section{Changes in demographic structures}

At the time of the construction of the HPP "Zvornik", there were sharp and unusual changes in some demographic structures (particulary sex, ethnic and structure of active population who perform occupation). The 1953 census shows the extreme and curiosity values of these population indicators in Mali Zvornik, while the changes were significantly less pronounced in rural settlements. With the completion of the construction of the HPP "Zvornik", the most of these demographic structures returned to "normal".

According to the 1953 census, the sex ratio of the population of Mali Zvornik was disturbed by the immigration of construction workers (almost exclusively male). Due to the greater number of male victims in the Second World War, in 1948 women constituted $51.4 \%$ of the total population of the Municipality of Mali Zvornik, and 51.1\% in Mali Zvornik (table 5). By immigra- 
tion of the labor force that participated in the construction of HPP "Zvornik", the share of men in the total population of the Municipality grew rapidly and according to the 1953 census it was 53.0\%. That same year in Mali Zvornik, out of a total of 2,783 inhabitants, as many as 1,854 (or 66.6\%) were men. After the completion of the construction of the HPP "Zvornik", most of the workers moved out, so that the data from the 1961 census show that the balanced sex ratio was restored in Mali Zvornik and in the whole Municipality.

Migrations at the time of the construction of the HPP "Zvornik" influenced a significant change in the ethnic composition of Mali Zvornik and Sakar, in which by the mid-20th century the predominantly Muslim population lived. Unlike other parts of the Municipality of Mali Zvornik, these two settlements remained part of Otoman Empire until the Congress of Berlin (1878), as only Muslim oases on the right bank of the Drina in Serbia (Lory, 2002). The immigration of Serbs began in 1879, but the Muslims remained the majority population - in 1921, they constituted $75.2 \%$, and in 1931, 69.3\% of the population of Mali Zvornik and Sakar (Josić, 1986).

Table 5 - Sex ratio in the period 1948-1961

\begin{tabular}{|c|c|c|c|c|c|c|c|c|c|c|}
\hline \multirow{2}{*}{ Year } & \multicolumn{4}{|c|}{ Municipality of Mali Zvornik } & \multicolumn{5}{c|}{ Mali Zvornik } \\
\cline { 2 - 11 } & total & men & $\%$ & women & \% & total & men & $\%$ & women & $\%$ \\
\hline 1948 & 9,036 & 4,394 & 48.6 & 4,642 & 51.4 & 768 & 383 & 48.9 & 385 & 51.1 \\
\hline 1953 & 12,004 & 6,367 & 53.0 & 5,637 & 47.0 & 2,783 & 1,854 & 66.6 & 929 & 33.4 \\
\hline 1961 & 11,583 & 5,759 & 49.7 & 5,824 & 50.3 & 1,888 & 943 & 49.9 & 945 & 50.1 \\
\hline
\end{tabular}

Source: SZSE, 1951; SZS, 1958; SZS, 1965a.

At the time of the construction of the HPP "Zvornik" (1948-1955), the ethnic composition of these two settlements was abruptly changed. However, the data on the ethnic composition in 1948 and 1953 census were not objective because the Muslim population was classified as a "Serb", "Muslim-undefined", "Yugoslav-undefined", or "others". The 1961 census (when a category "Muslims in an ethics sense" was introduced) give a more objective picture of ethnic changes at the time of the construction of the HPP "Zvornik". In that year, the ethnic composition of Mali Zvornik was made up of $68.6 \%$ of Serbs and $12.7 \%$ of Muslims, while $51.5 \%$ of Muslims and $47.7 \%$ of Serbs lived in Sakar (SZS, 1994). This change in the ethnic structure was influenced by the immigration of construction workers of Serbian nationality and the emigration of the Muslims. 
Collection of Papers - Faculty of Geography at the University of Belgrade 65 (1)

Table 6 - Active population who perform occupation in the period 1953-1961

\begin{tabular}{|l|c|c|c|c|c|c|c|c|}
\hline \multirow{2}{*}{$\begin{array}{l}\text { Type of } \\
\text { occupation }\end{array}$} & \multicolumn{3}{|c|}{ Municipality of Mali Zvornik } & \multicolumn{4}{c|}{ Mali Zvornik } \\
\cline { 2 - 10 } & \multicolumn{2}{|c|}{$\mathbf{1 9 5 3}$} & \multicolumn{2}{c|}{$\mathbf{1 9 6 1}$} & \multicolumn{2}{|c|}{1953} & \multicolumn{2}{c|}{1961} \\
\cline { 2 - 9 } & number & $\%$ & number & $\%$ & number & $\%$ & number & $\%$ \\
\hline agriculture & 4,184 & 65.4 & 3,402 & 69.3 & 128 & 7.8 & 163 & 23.6 \\
\hline construction & 1,564 & 24.4 & 153 & 3.1 & 1,378 & 83.5 & 86 & 12.4 \\
\hline other & 649 & 10.2 & 1,356 & 27.6 & 144 & 8.7 & 443 & 64.0 \\
\hline total & 6,397 & 100.0 & 4,911 & 100.0 & 1,650 & 100.0 & 692 & 100.0 \\
\hline
\end{tabular}

Source: SZS, 1958; SZS, 1965b.

During the period 1948-1961, the change in the occupational structure of the active population in Municipality of Mali Zvornik, in addition to socioeconomic processes that affected the whole of Serbia (deagrarization, industrialization, etc.), was largely influenced by the labour immigration for the construction of HPP "Zvornik". The most extreme changes were recorded in the number of construction workers and their share in the active population. In the entire Municipality, in 1953 construction workers accounted for almost a quarter of the active population (24.4\%). In Mali Zvornik, construction workers accounted for as much as $83.5 \%$ in the active population (table 6). With the completion of construction of HPP "Zvornik" the number of construction workers decreased sharply. In 1961, these workers accounted for $3.1 \%$ in the total active population in the municipality, and $12.4 \%$ in Mali Zvornik.

In addition to the general deagrarization and industrialization process, the reduction of the number of active agricultural population in Municipality of Mali Zvornik was largely influenced by the creation of Zvornik Lake, when seven settlements lost the most fertile agricultural areas in the Drina valley. The share of farmers in the active population in 1953 (65.4\%) was lower in relation to the neighboring municipalities, partly because of the large influx of construction workers. The process of deagrarization, intensified by the submerging of agricultural land and the displacement of the population, had an impact on the reduction of the number of active farmers in the period 1953-1961 for $18.7 \%$. However, in the same period the share of farmers in the active population increased to $69.3 \%$ (table 6), as a result of the emigration of construction workers after the completion of the construction of of the HPP "Zvornik". In settlements on the shore of Zvornik Lake, the number of persons working in agriculture fell by $22.5 \%$, and in villages 
that did not lose fertile land by $16.7 \%$. The largest decrease in the number of active farmers had Culine (45.8\%), Čitluk (30.5\%), Amajić (27.6\%), Budisić (25.3\%) and Velika Reka (18.9\%) (SZS, 1958, 1965b).

The construction of the HPP "Zvornik" was one of the causes of the abortion of boating and rafting, traditional occupations of the population of this part of Drina valley. Locals of Mali Zvornik and Sakar were sailed along Drina and Sava by authentic boats (so-called "zvornikuše" or "burinke") and transported merchandise to Brčko and Belgrade. By building a dam, as physical barrier to the movement of boats and rafts, these traditional occupations have disappeared (Голић, 2010b).

\section{Conclusion}

The results of the research confirmed the theoretical considerations on the impact of dam construction and the formation of reservoirs on demographic changes. The analysis showed that in the municipality of Mali Zvornik in the period 1948-1961 significant deviations from the expected demographic processes occurred. Between the census years there were rapid and non-linear changes in some demographic indicators. The largest deviations were recorded in the change of population and number of households. Some demographic indicators in Mali Zvornik were curiosity and record in Serbia (population growth rate, households growth rate, average household size, share of single-member households, sex ratio, share of construction workers in the active population, etc.).

The analyzed census data show that non-linear demographic trends were characteristic of Mali Zvornik and villages on the shore of Zvornik Lake, while in other rural settlements there were no significant deviations from the demographic trends of that time in Serbia. This indicates the existence of a direct link between the construction of HPP "Zvornik" and demographic changes in settlements that have lost some of their parts by submersion.

The direct impact of the construction of HPP "Zvornik" on demographic processes in Municipality of Mali Zvornik was finished with the 1961 census, and the results of the following censuses did not show unusual changes. In the later period, in accordance with the socio-economic changes affecting the whole of Serbia, demographic trends corresponded to general population trends in the larger part of the country (declining birth rates and natural growth, increasing mortality rate, depopulation of rural settlements, 
population ageing, reducing the number of agricultural population, increase the number of employees in the secondary sector and service activities, etc.). According to the 2011 census, there are 12,482 inhabitants in the Municipality of Mali Zvornik - 11.3\% less than in 2002 (P3C, 2014a), and depopulation and demographic ageing are present in all settlements.

\section{Acknowledgements}

The paper is the result of the research within the project no. 176008 funded by the Ministry of Education and Science of the Republic of Serbia.

\section{References}

Golić, R., \& Joksimović, M. (2013). Plutajući nanos kao ekološki problem Zvorničkog jezera. U Planska i normativna zaštita prostora $i$ životne sredine, knjiga 1 (str. 405-412). Beograd: Asocijacija prostornih planera Srbije, Beograd: Univerzitet u Beogradu - Geografski fakultet.

Gutman, P.S. (1994). Involuntary resettlement in hydropower projects. Annual Review of Energy and the Environment, 19, 189-210. doi: 10.1146/annurev.eg.19.110194.001201

Hadi, A. (2017). Dams and displacement in Turkey and Pakistan. European Journal of Economics and Business Studies, 8(1), 241-246.

Josić, P. (1986). Rađevina između dva svetska rata. U R. Mihaljčić (ur.), Rađevina u prošlosti (str. 469-580). Krupanj: SO Krupanj.

Kirchherr, J., \& Charles, K.J. (2016). The social impacts of dams: A new framework for scholarly analysis. Environmental Impact Assessment Review, 60, 99-114. doi: 10.1016/j.eiar.2016.02.005

Lory, B. (2002). Mali Zvornik. Balkanologie, 6(1-2), 15-18.

Matić, R. et al. (2015). Analiza i proračun zasipanja nanosom akumulacije Zvornik do 2015. godine (dokumentacija). Mali Zvornik: Geodet DB.

Milinković, M. (2005). Na Drini brana. Mali Zvornik: HE „Zvornik”.

Namy, S. (2007). Addressing the social impacts of large hydropower dams. The Journal of International Policy Solutions, 7, 11-17.

Nguyen, H.T., Pham, T.H., \& de Bruyn, L.L. (2017). Impact of hydroelectric dam development and resettlement on the natural and social capital of 
rural livelihoods in Bo Hon village in central Vietnam. Sustainability, 9(8), 1-15. doi: 10.3390/su9081422

Owusu, K., Obour, P.B., \& Nkansah, M A. (2017). Downstream effects of dams on livelihoods of river-dependent communities: the case of Ghana's Kpong Dam. Geografisk Tidsskrift - Danish Journal of Geography, 117(1), 1-10. doi: 10.1080/00167223.2016.1258318

Pavlović, M., Golić, R., \& Šabić, D (2010). The Influence of water resources on transformation of spatial-functional structure of the territory of the Municipality of Mali Zvornik and the possibilities for the construction of new hydro power plants. Bulletin of the Serbian Geographical Society, 90(3), 199-206. doi: 10.2298/GSGD1003189P

Ristanović, S. (1985). Prvenac na Drini - hidroelektrana Zvornik. Loznica: Podrinje.

SZS (1958). Popis stanovništva 1953. Knj. XIV, Osnovni podaci o stanovništvu. Beograd: Savezni zavod za statistiku (SZS).

SZS (1965a). Popis stanovništva 1961. Knj. XI, Pol i starost. Beograd: Savezni zavod za statistiku (SZS).

SZS (1965b). Popis stanovništva 1961. Knj. XIV, Aktionost i delatnost. Beograd: Savezni zavod za statistiku (SZS).

SZS (1994). Popis stanovništva, domaćinstava i stanova u 1961. Knj. III, Nacionalni sastav stanovništva FNR Jugoslavije po naseljima i opštinama. Beograd: Savezni zavod za statistiku (SZS).

SZSE (1951). Konačni rezultati popisa stanovništva od 15. marta 1948. godine. Knj. I, Stanovništvo po polu i domaćinstva. Beograd: Savezni zavod za statistiku i evidenciju (SZSE).

Tan, Y., \& Hugo, G. (2011). Demographic impacts of the Three Gorges Dam. In D.S. Brunn (ed.), Engineering earth: The impacts of megaengineering projects (pp. 1583-1598). Dordrecht: Springer Verlag. doi: 10.1007/978-90481-9920-4_91

Tilt, B., Braun, Y., \& He, D. (2009). Social impacts of large dam projects: A comparison of international case studies and implications for best practice. Journal of Environmental Management, 90, S249-S257. doi: 10.1016/j. jenvman.2008.07.030

WCD (2000). Dams and development: A new framework for decision making. The Report of the World Commission on Dams (WCD). London: Earthscan Publishers. 
Wilmsen, B. (2017). Damming China's rivers to expand its cities: the urban livelihoods of rural people displaced by the Three Gorges Dam. Urban Geography, 1-22. doi: 10.1080/02723638.2017.1328578

Wilmsen, B., \& Van Hulten, A. (2017). Following resettled people over time: the value of longitudinal data collection for understanding the livelihood impacts of the Three Gorges Dam, China. Impact assessment and project appralsal, 35(1), 94-105. doi: 10.1080/14615517.2016.1271542

Wilmsen, B., \& Webber, M. (2017). Mega dams and resistance: the case of the Three Gorges Dam, China. In J. Grugel, J.N. Singh, L. Fontana, A. Uhlin (eds.), Demanding justice in the global South (pp. 69-98). Cham, Switzerland: Palgrave Macmillan. doi: 10.1007/978-3-319-38821-2_4

Wu, Z., Penning, M. J., Zeng, W., Li, S., \& Chappell, N. L. (2016). Relocation and social support among older adults in rural China. Journals of Gerontology, Series B, 71(6), 1108-1119. doi: 10.1093/geronb/gbu187

Yan, D., Shi, G., Hu, Z., \& Wang, H. (2017). Resettlement for the Danjiangkou Dam heightening project in China: planning, implementation and effects. International Journal of Water Resources Development, 33(4), 609-627. doi: 10.1080/07900627.2016.1216829

Yang, S., Smith, L., \& Sivakumar, M. (2017). Assessment of social and environmental impacts of coastal reservoirs. Journal of Sustainable Urbanization, Planning and Progress, 2(2). doi: 10.26789/JSUPP.2017.02.012

Yen, C.T.T. (2003). Towards sustainability of Vietnam's large dams - Resettlement in hydropower projects. Stockholm: Royal Institute of Technology, Department of Infrastructure.

Ђурић, В. (1960). Промене у насељима у ФНР Југославији. Насеља и порекло становништва, 36; Српски етнографски зборник, 74, 243-418.

Гавриловић, Љ., Михајловић, Б., Макаров, С., \& Милинчић, М. (2011). Изворишта површинских вода у пограничном простору Србије према Македонији - заштита и валоризација у функцији водоснабдевања. Зборник радова Географског факултета, 59, 77-108.

Голић, Р. (2010а). Природни потенцијали у функцији регионалног развоја Малозворничког краја (магистарски рад). Београд: Универзитет у Београду - Географски факултет.

Голић, Р. (2010б). Зворничке лађе и сплаварење на Дрини. Глобус, 35, 81-98. 
Голић, Р. (2015). Утицај ХЕ “Зворник” на режим наноса и морфолошке процесе у долини Дрине. У 4. српски конгрес географа са међународним учешћем "Достигнућа, актуелности и изазови географске науке и праксе". Зборник радова, књига 2 (стр. 429-434). Београд: Универзитет у Београду - Географски факултет.

Голић, Р., Јоксимовић, М., \& Крстић, Ф. (2014). Утицај водних акумулација на демографске промене - пример ХЕ “Зворник”. У Географрско образовање, наука и пракса: развој, стаюе и перспективе - зборник радова (стр. 311-318). Београд: Универзитет у Београду - Географски факултет.

Милинчић, М., Павловић, М., \& Шабић, Д. (2010). Глобалне и регионалне промене: утицај водних акумулација на регионалну трансформацију географског простора. Зборник радова Географског факултета, 58, 121-136.

РЗС (2014а). Попис становништва, домаћинстава и станова 2011. у Републиизи Србији. Књ. 20, Упоредни преглед броја становника 1948-2011. Београд: Републички завод за статистику (РЗС).

РЗС (2014б). Попис становништва, домаћинстава и станова 2011. у Републици Србији. Књ. 21, Упоредни преглед броја домаћинстава 1948-2011. и станова 1971-2011. Београд: Републички завод за статистику (РЗС).

Станковић, С. (2004). Лимнолошки објекти у сливу Дрине. У Јован Цвијић и Подриюе (стр. 102-126). Лозница: Центар за културу “Вук Караџић”. 